University of Nebraska - Lincoln

DigitalCommons@University of Nebraska - Lincoln

Faculty Publications: Department of

Entomology

Entomology, Department of

$8-2014$

\title{
Characterization of Greenbug Feeding Behavior and Aphid (Hemiptera: Aphididae) Host Preference in Relation to Resistant and Susceptible Tetraploid Switchgrass Populations
}

\author{
Kyle G. Koch \\ University of Nebraska-Lincoln, kkoch4@unl.edu \\ Nathan Palmer \\ USDA-ARS, nathan.palmer@ars.usda.gov \\ Mitch Stamm \\ University of Nebraska-Lincoln \\ Jeff D. Bradshaw \\ University of Nebraska-Lincoln, jbradshaw2@unl.edu \\ Erin Blankenship \\ University of Nebraska-Lincoln, erin.blankenship@unl.edu
}

See next page for additional authors

Follow this and additional works at: https://digitalcommons.unl.edu/entomologyfacpub

Part of the Entomology Commons

Koch, Kyle G.; Palmer, Nathan; Stamm, Mitch; Bradshaw, Jeff D.; Blankenship, Erin; Baird, Lisa M.; Sarath, Gautam; and Heng-Moss, Tiffany M., "Characterization of Greenbug Feeding Behavior and Aphid (Hemiptera: Aphididae) Host Preference in Relation to Resistant and Susceptible Tetraploid Switchgrass Populations" (2014). Faculty Publications: Department of Entomology. 425.

https://digitalcommons.unl.edu/entomologyfacpub/425

This Article is brought to you for free and open access by the Entomology, Department of at DigitalCommons@University of Nebraska - Lincoln. It has been accepted for inclusion in Faculty Publications: Department of Entomology by an authorized administrator of DigitalCommons@University of Nebraska - Lincoln. 


\section{Authors}

Kyle G. Koch, Nathan Palmer, Mitch Stamm, Jeff D. Bradshaw, Erin Blankenship, Lisa M. Baird, Gautam Sarath, and Tiffany M. Heng-Moss 


\title{
Characterization of Greenbug Feeding Behavior and Aphid (Hemiptera: Aphididae) Host Preference in Relation to Resistant and Susceptible Tetraploid Switchgrass Populations
}

\author{
Kyle G. Koch • Nathan Palmer • Mitch Stamm • \\ Jeff D. Bradshaw • Erin Blankenship • Lisa M. Baird • \\ Gautam Sarath • Tiffany M. Heng-Moss
}

Published online: 1 August 2014

(C) Springer Science+Business Media New York 2014

\begin{abstract}
Two choice studies were performed to evaluate greenbug, Schizaphis graminum (Rondani), and yellow sugarcane aphid, Sipha flava (Forbes), preference for two tetraploid switchgrass populations, Summer and Kanlow, and one experimental hybrid, $\mathrm{K} \times \mathrm{S}$, derived by crossing Kanlow $($ male $) \times$ Summer (female) plants. Additionally, an assessment of $S$. graminum feeding behavior was performed on the same switchgrass populations, by using the electrical penetration graph (EPG) technique. Choice studies for S. flava indicated a lack of antixenosis, with no preference by aphids among any of the switchgrass populations at any time point. However, choice studies with $S$. graminum indicated a preference for the $\mathrm{K} \times \mathrm{S}$ plants at $24 \mathrm{~h}$ after aphid introduction. No obvious differences were observed for the leaf surfaces between the three populations. Feeding behavior studies for $S$. graminum
\end{abstract}

Electronic supplementary material The online version of this article (doi:10.1007/s12155-014-9510-0) contains supplementary material, which is available to authorized users.

K. G. Koch • M. Stamm • T. M. Heng-Moss ( $₫)$

Department of Entomology, University of Nebraska, 201B

Entomology Hall, Lincoln, NE 68583-0816, USA

e-mail: thengmoss2@unl.edu

N. Palmer · G. Sarath

Grain, Forage and Bioenergy Research Unit, USDA-ARS, Lincoln, NE 68583, USA

J. D. Bradshaw

Department of Entomology, Panhandle Research \& Extension

Center, University of Nebraska, Scottsbluff, NE 69361, USA

E. Blankenship

Department of Statistics, University of Nebraska, Lincoln, NE 68583, USA

L. M. Baird

Department of Biology, University of San Diego, San Diego,

CA 92110, USA on switchgrasses indicated no differences for the time to first probe or time to first sieve element phase among switchgrass populations. However, duration of sieve element phases for $S$. graminum was significantly less on Kanlow compared to $\mathrm{K} \times \mathrm{S}$ and Summer. $S$. graminum also had a significantly lower potential phloem ingestion index (PPII) and few aphids showing sustained phloem ingestion on Kanlow as compared to $\mathrm{K} \times \mathrm{S}$ and Summer plants. These results suggest that resistance factors (chemical or mechanical) in Kanlow are located in the phloem tissue. At the whole leaf level, some differences were observed for a subset of polar metabolites, although Kanlow plants were significantly enriched for oxalic acid.

Keywords Choice studies · EPG $\cdot$ Feeding behavior . Greenbug $\cdot$ Plant resistance $\cdot$ Tetraploid switchgrass $\cdot$ Yellow sugarcane aphid

\section{Introduction}

Switchgrass, Panicum virgatum L., is a widely distributed, polyploid warm-season perennial grass with excellent potential as a biomass crop [8]. However, long-term sustainability of switchgrass as a bioenergy feedstock will require efforts directed at improved biomass yield under a variety of biotic and abiotic stress factors.

Insect pests contribute significantly to over US\$1 billion crop losses through both direct and indirect injury, and it can be anticipated that bioenergy crops will be no exception to insect-related losses in yields. Recently, Koch et al. [26, 27] have shown that tetraploid switchgrasses can serve as suitable hosts for two different aphids, namely the greenbug, Schizaphis graminum (Rondani), and the yellow sugarcane aphid, Sipha flava (Forbes). Both aphids can be found across 
the USA and have been well characterized as pests of many cultivated and native grasses [6, 7, 24, 31].

Aphids are particularly important crop pests and may cause plant damage by removing photo assimilates and transmitting an array of plant viruses [44]. During feeding, the stylets of the aphid's piercing-sucking mouthparts penetrate plant tissue to feed on phloem sieve elements $[11,37,44,52]$. Penetrations of plant tissues by aphids can be monitored by the electrical penetration graph (EPG) technique [52], and stylet penetrations may provide cues about host-plant acceptance or rejection [51, 52]. The EPG technique was first described by McLean and Kinsey [30], using an alternating current (AC) recorder system, and later by Tjallingii [47], using a direct current (DC)-based monitor. The EPG technique allows the recording of signal waveforms corresponding to different insect activities and the position of the stylet tips within the plant tissues [48, 52]. Further, when considered in combination, stylet activities and position may be useful in determining the kind of resistance mechanisms that may be involved at the plant tissue level [10, 11, 21, 53].

Although the EPG technique has been widely used to study the feeding behavior of several species of aphids on many host plants [53], no studies have documented aphid feeding behavior on switchgrass. Further, no attempt has been made to document the presence of antixenosis within switchgrass populations to potential insect pests. Therefore, the specific objectives of this research were to characterize the expression of antixenosis among selected switchgrass populations of $S$. graminum and $S$. flava and compare $S$. graminum feeding behavior on resistant and susceptible switchgrasses using the EPG technique.

\section{Materials and Methods}

Plant Material Choice studies and EPGs were performed among two switchgrass cultivars (populations), Kanlow and Summer, and one experimental strain, $\mathrm{K} \times \mathrm{S}$. The origin of these cultivars and experimental strain has been published [26, 27]. The experimental strain was developed by Dr. Kenneth Vogel, USDA-ARS (retired), Lincoln, NE, who also provided seeds of the cultivars.

Insect Colonies Choice studies, to assess aphid preference among switchgrass populations, were conducted with $S$. graminum (biotype I) and $S$. flava. In addition, EPGs to assess aphid feeding behavior were performed for S. graminum (biotype I). Colonies for both aphid species were obtained from Dr. John D. Burd, USDA-ARS in Stillwater, OK. S. graminum and S.flava were maintained on sorghum and barley, respectively, as described by Koch et al. [27].
Antixenosis Studies Choice studies were performed for both $S$. graminum and $S$. flava to assess aphid preference among the three switchgrass populations. Plants were grown in plastic nursery pots $(9 \mathrm{~cm}$ in diameter by $9 \mathrm{~cm}$ in depth) containing a Fafard Growing Media (Mix No. 3B) (Conrad Fafard, Agawam, MA). One seed of each population of switchgrass (Kanlow, Summer, and $\mathrm{K} \times \mathrm{S}$ ) was planted approximately $2 \mathrm{~cm}$ from the perimeter of the pot. Within a pot, seeds for each population were equally spaced from each other and the center of the pot $(5.2 \mathrm{~cm}$ between grasses and $3 \mathrm{~cm}$ from center) and randomly seeded with relation to each other. A total of ten pots were used. Plants were maintained in a greenhouse at $25 \pm 7^{\circ} \mathrm{C}$ with the lighting augmented by 400 W metal-halide lamps to produce a photoperiod of 16:8 (L:D) $\mathrm{h}$ until the plants reached the V1 developmental stage, as described by Moore et al. [32]. Plants were fertilized every 2 weeks with a water-soluble (20:10:20 N-P-K) fertilizer.

Prior to introduction, aphids were placed in a petri dish and starved for approximately $1 \mathrm{~h}$. Following the pretreatment, 50 adult apterous aphids were introduced onto filter paper $(1.5 \mathrm{~cm}$ in diameter) in the center of the arena. Pots were then arranged within a heavy-duty plastic flat $(\sim 50 \mathrm{~cm}$ in length by $36 \mathrm{~cm}$ in width by $7.6 \mathrm{~cm}$ in depth) filled with water to prevent aphids from moving between pots. The number of aphids was visually documented by counting on each switchgrass population at 1, 2, 4, 8, 24, 48, and $72 \mathrm{~h}$ after aphid introduction. Experiments were conducted in a controlled laboratory setting at $23 \pm 5{ }^{\circ} \mathrm{C}$ with continuous light. The experimental design was a randomized complete block design with 10 replications per experiment.

Choice studies were analyzed as a repeated measures design using generalized linear mixed model analyses (PROC GLIMMIX) [41] to identify differences in aphid preference for resistant and susceptible switchgrass populations. The corrected Akaike's information criterion (AICC) fit statistic was used to determine the most appropriate covariance structure, and the first-order autoregressive [AR (1)] covariance structure was selected. Switchgrass population and evaluation time were considered random effects. When appropriate, means were separated using Fisher's least significant difference (LSD) procedure $(\alpha=0.05)$.

EPG Recording For the feeding behavior study, plants were grown in SC-10 Super Cell Single Cell Cone-tainers (3.8-cm diameter by $21 \mathrm{~cm}$ deep) (Stuewe \& Sons, Inc., Corvallis, OR) containing a Fafard Growing Media (Mix No. 3B) (Conrad Fafard, Agawam, MA) and were maintained as previously described for the choice study. After emergence, plants were thinned down to one plant per cone-tainer. Switchgrass plants were grown to the V1 developmental stage for all recordings and were selected based on uniformity. Before recordings, plants were transferred from the greenhouse to the laboratory $\left(23 \pm 5^{\circ} \mathrm{C}\right)$ and allowed to acclimate for approximately $2 \mathrm{~h}$. 
Feeding behavior of $S$. graminum was evaluated using the EPG-DC system described by Tjallingii [47]. Recordings were performed using a Giga-8 EPG model (EPG Systems, Wageningen, The Netherlands) with a $10^{9} \Omega$ resistance amplifier and an adjustable voltage. Output from the EPG was digitized at a sample rate of $100 \mathrm{~Hz}$ (100 samples per sec) per channel using a built-in data logger (DI-710, Dataq Instruments Inc., Akron, OH) and recorded on a computer with EPG acquisition software (Stylet+, EPG Systems, Wageningen, The Netherlands). Voltage was monitored for fluctuations on the computer and adjusted at $\pm 5 \mathrm{~V}$ as needed, while the gain was adjusted from 50 to $100 \times$ in order to improve the quality of the recording.

Adult, apterous $S$. graminum were preconditioned on the susceptible $\mathrm{K} \times \mathrm{S}$ population for $24 \mathrm{~h}$ prior to all recordings. Aphids were then placed in a petri dish and denied food $1 \mathrm{~h}$ prior to recordings to increase the likelihood of feeding and to allow resheathing of their stylets [3]. An individual plant and insect were integrated to complete an electrical circuit using a copper electrode (plant electrode), stuck in the moist soil of the potted plant, and a gold wire $(99.99 \%, 10-\mu \mathrm{m}$ diameter and 2-3-cm length; Sigmund Cohn Corp., Mount Vernon, NY) attached to the dorsum of a single aphid by a silver conductive glue [ $4 \mathrm{ml}$ water with one drop of Triton X-100, $4 \mathrm{~g}$ water-soluble glue (Scotch clear paper glue, non-toxic; $3 \mathrm{M}$, St. Paul, MN), and $4 \mathrm{~g}$ silver flake (99.95\%, size, 8$10 \mu \mathrm{m}$, Inframat Advanced Materials, Manchester, CT)]. The opposite end of the gold wire was attached to a 24-gauge copper wire ( $\approx 2-\mathrm{cm}$ length), which was soldered to a copper nail $(1.6 \times 19.0 \mathrm{~mm})$. After the aphids were fixed to the gold wire, the electrode was inserted into the head-stage amplifier (EPG probe). The EPG probe was an amplifier with a 1-gigaohm input resistance and 50× gain [48, 49]. At the completion of the starvation period, wired aphids were placed on the adaxial side of the newest, fully developed leaf. Aphid placement was considered successful if the individual was able to move freely on the leaf surface [46]. Plants on which no feeding occurred or for which no reliable signals were obtained were not included in further analyses. All plants, EPG probes, and plant electrodes were placed inside one of two Faraday cages, constructed from aluminum mesh wire with an aluminum frame and base $(61 \mathrm{~cm} \times 61 \mathrm{~cm} \times 76 \mathrm{~cm})$, in order to protect the EPG's internal conductors from electrical and environmental noise $[10,46]$. Recordings were made on eight plants simultaneously, with at least one plant of each of the three switchgrass populations represented in each recording. The feeding behavior of $S$. graminum was recorded for $15 \mathrm{~h}$ with 20 replications per switchgrass population. Recordings began mid-afternoon and were maintained under continuous fluorescent light.

EPG procedures were followed from van Helden and Tjallingii [53], while EPG waveforms were differentiated and categorized according to Reese et al. [38]. The waveforms are grouped into three main behavioral phases: pathway phase, xylem, and phloem or sieve element phase [36, 38, 52]. The pathway phase (waveforms A, B, and C) is characterized by intercellular stylet penetration and withdrawal, periods of no stylet movement, and brief intracellular punctures by stylet tips, also known as potential drops (waveform pd) $[22,36]$. For simplification, differences between waveforms $\mathrm{A}, \mathrm{B}$, and $\mathrm{C}$ were not defined in the study and the three waveforms were generically labeled as waveform $\mathrm{C}[1,16$, 46]. Waveform F (stylet penetration problems) were not common in the recordings and were included in the pathway phase whenever they were observed [11]. The xylem phase (waveform $G$ ) is characterized by active drinking of water from xylem elements $[34,45,50]$. The sieve element phase reflects salivation secretions (waveform E1) and ingestion of phloem sap (waveform E2). Waveforms E1 and E2 can be difficult to distinguish; therefore, the two waveforms were combined and labeled generally as waveform $\mathrm{E}$ to depict general penetration activities of $S$. graminum in phloem tissues [2, 3, 46].

EPG feeding behavior parameters were selected from the Sarria Excel Notebook [40]. The calculated parameters included the mean time from start of recording to first probe (elapsed time of placement of aphid on the plant to insertion of mouthparts) and first sieve element phases; time from the first aphid probe to first sieve element phase; total number of potential drops, pathway phases (n-PP), sieve element phases, xylem phases, non-probing events, and probes after first sieve element phases; sum of duration of pathway phases, sieve element phases, xylem phases, non-probing events, first probe, and first sieve element phase; and potential phloem ingestion index (PPII) and percent of aphids with sustained phloem ingestion $(E>10 \mathrm{~min})$.

EPG files were annotated by waveform and the duration of each was calculated in Microsoft Excel Workbook. Data were combined, separated by switchgrass population and aphid number (replication), and converted to comma-separated values (CSV). The combined data were checked for errors using a beta program designed for SAS software [41]. Once errors in waveform labeling were corrected, the data were tested for significance by using analysis of variance (ANOVA), implemented in PROC GLIMMIX. When appropriate, means were separated using Fisher's least significant difference (LSD) test $(\alpha=0.05)$. Normality was assessed for all parameters using graphical analysis of the residuals and a Shapiro-Wilk test [42]. A log transformation was performed for data that did not follow a normal distribution. Transformed data were reconverted to the original scale for summarization in all figures and tables.

Scanning Electron Microscopy Leaf surface morphology was determined using scanning electron microscopy (SEM) to discern any noticeable differences of the leaf surfaces. Seedlings for Kanlow, Summer, and $\mathrm{K} \times \mathrm{S}$ were grown to the $\mathrm{V} 1$ 


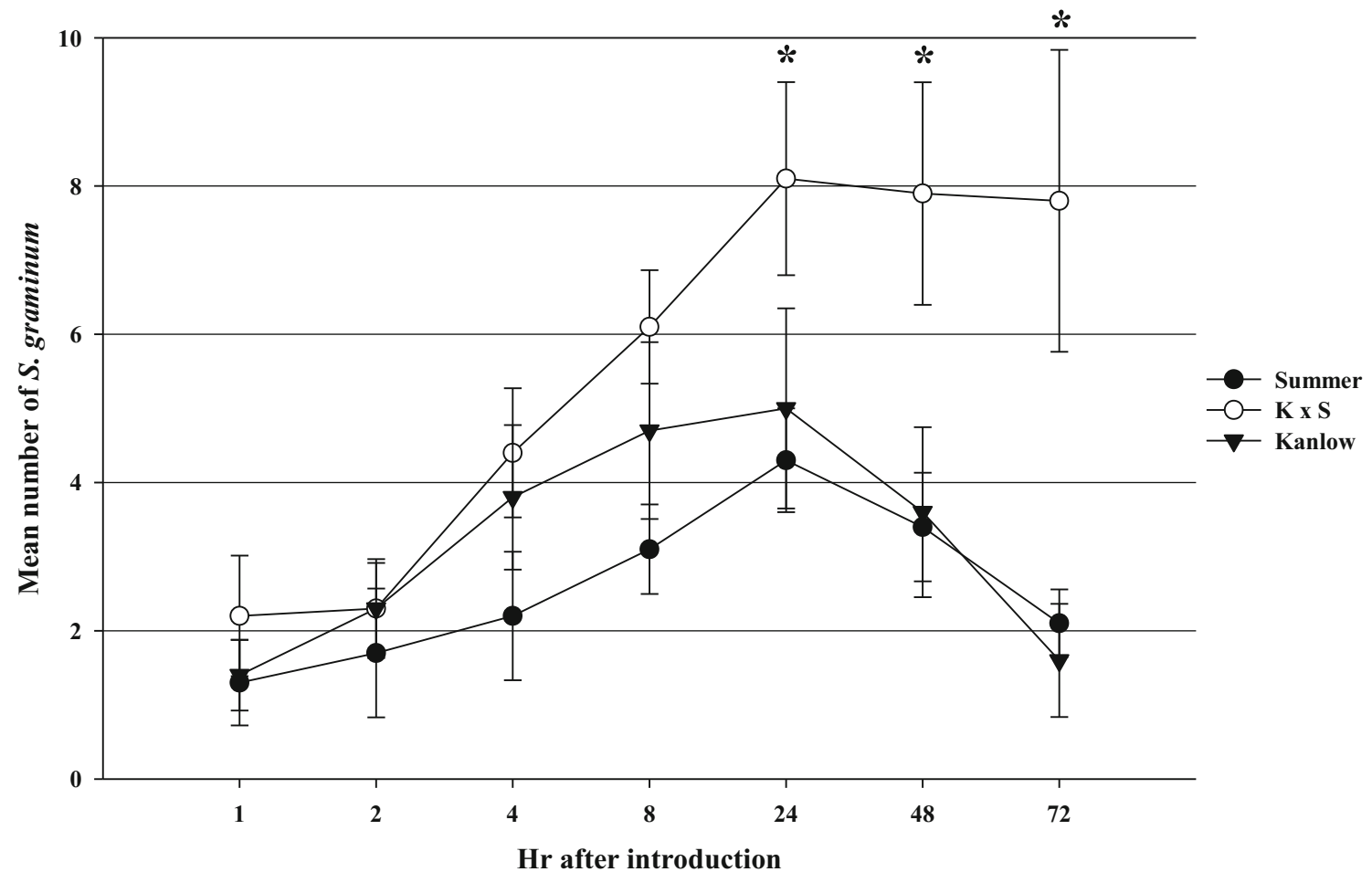

Fig. 1 Comparison of Schizaphis graminum preference among switchgrasses. ${ }^{*} P \leq 0.05$ denotes significant differences (LSD test) within a given evaluation time in hours $(\mathrm{Hr})$

stage, and the second fully expanded leaves were cut into small pieces $(\sim 2-4 \mathrm{~mm})$ and fixed in a solution of ethanol/ acetic acid $(3: 1 v / v)$ overnight at $\sim 6^{\circ} \mathrm{C}$. Tissues were washed with $80 \%$ aqueous ethanol and subsequently prepared for scanning electron microscopy. Tissues were critical point dried, mounted onto SEM holders, sputter coated with chromium, and viewed on a Hitachi S4700 field emission scanning electron microscope set at $5 \mathrm{kV}$.

Metabolite Analysis Thirty seedlings each for Kanlow, Summer, and $\mathrm{K} \times \mathrm{S}$ populations were grown to the $\mathrm{V} 1$ stage as previously described for the EPG study. At the V1 stage, shoots were harvested and combined into three pools of 10 seedlings each for all three populations and flash frozen in liquid nitrogen. Tissue samples were cryogenically ground and stored at $-80{ }^{\circ} \mathrm{C}$ until further analysis [33]. Metabolites were extracted from the plant tissue as described by Roessner et al. [39]. Briefly, $350 \mu \mathrm{L}$ of $100 \%$ methanol was added to $100 \mathrm{mg}$ of ground plant material in a microfuge tube, and the samples were then heated in a $70{ }^{\circ} \mathrm{C}$ heat block for $15 \mathrm{~min}$. After heating, an additional $350 \mu \mathrm{L}$ of ultrapure water was added to each sample, which was then vigorously mixed and centrifuged at $20,000 \times \mathrm{g}$ for $10 \mathrm{~min}$. The supernatants were transferred to new $1.5-\mathrm{mL}$ tubes and nonpolar metabolites removed by two $300-\mu \mathrm{L}$ chloroform washes; $50 \mu \mathrm{L}$ of the final aqueous phase was transferred to a $2-\mathrm{mL}$ glass sample vial and evaporated to dryness under vacuum. Dried metabolites were resuspended in $50 \mu \mathrm{L}$ of pyridine and then trimethylsilylated at $50{ }^{\circ} \mathrm{C}$ for $2 \mathrm{~h}$ using $100 \mu \mathrm{L}$ of BSTFA with $1 \%$ TMCS (Thermo Scientific Inc.). Derivitized metabolites were separated using an Agilent 6850 Series II gas chromatograph with a 5973 mass selective detector and a HP-5MS $(30 \mathrm{~m}, 0.250 \mathrm{~mm}$ I.D.) column (Agilent Technologies, Inc.). Run parameters consisted of the injector temperature set at $250{ }^{\circ} \mathrm{C}$ and operating in split less mode with helium as a carrier gas at a constant flow rate of $0.6 \mathrm{~mL} / \mathrm{min}$. The initial oven temperature of $50{ }^{\circ} \mathrm{C}$ remained constant for $5 \mathrm{~min}$ after injection, and thereafter, the oven temperature increased at a rate of $10{ }^{\circ} \mathrm{C}$ per min to a maximum temperature of $325{ }^{\circ} \mathrm{C}$ which was held constant for an additional $5 \mathrm{~min}$. Metabolites were identified based on their ion spectra using the NIST mass spectra search program included with the Chem station software (Agilent Technologies, Inc.), and confidently identified metabolites of interest were quantitated based on their major ion peak areas.

Metabolites were tested for significance using an analysis of variance (ANOVA), implemented in PROC GLIMMIX. A $\log$ transformation was performed for data to allow for better comparison. Transformed data were reconverted to the original scale for summarization in all tables. Where appropriate, means were separated using Fisher's least significant difference (LSD) procedure $(\alpha=0.05)$. 
Fig. 2 Comparison of EPG parameters for duration of SE (sieve element) phases (a) and NP (non-probing) events (b), and stylet activities for pathway phases (c) and non-probing events (d). Phloem linked parameters based on potential phloem ingestion index (PPII) (e) and percentage of aphids showing sustained phloem ingestion $(E>$ $10 \mathrm{~min}$ ) (f). Bars with the same letter within a chart are not significantly different $(P>0.05)$, LSD test. Black bars, $\mathrm{K} \times \mathrm{S}$; light gray bars, Summer; gray bars, Kanlow
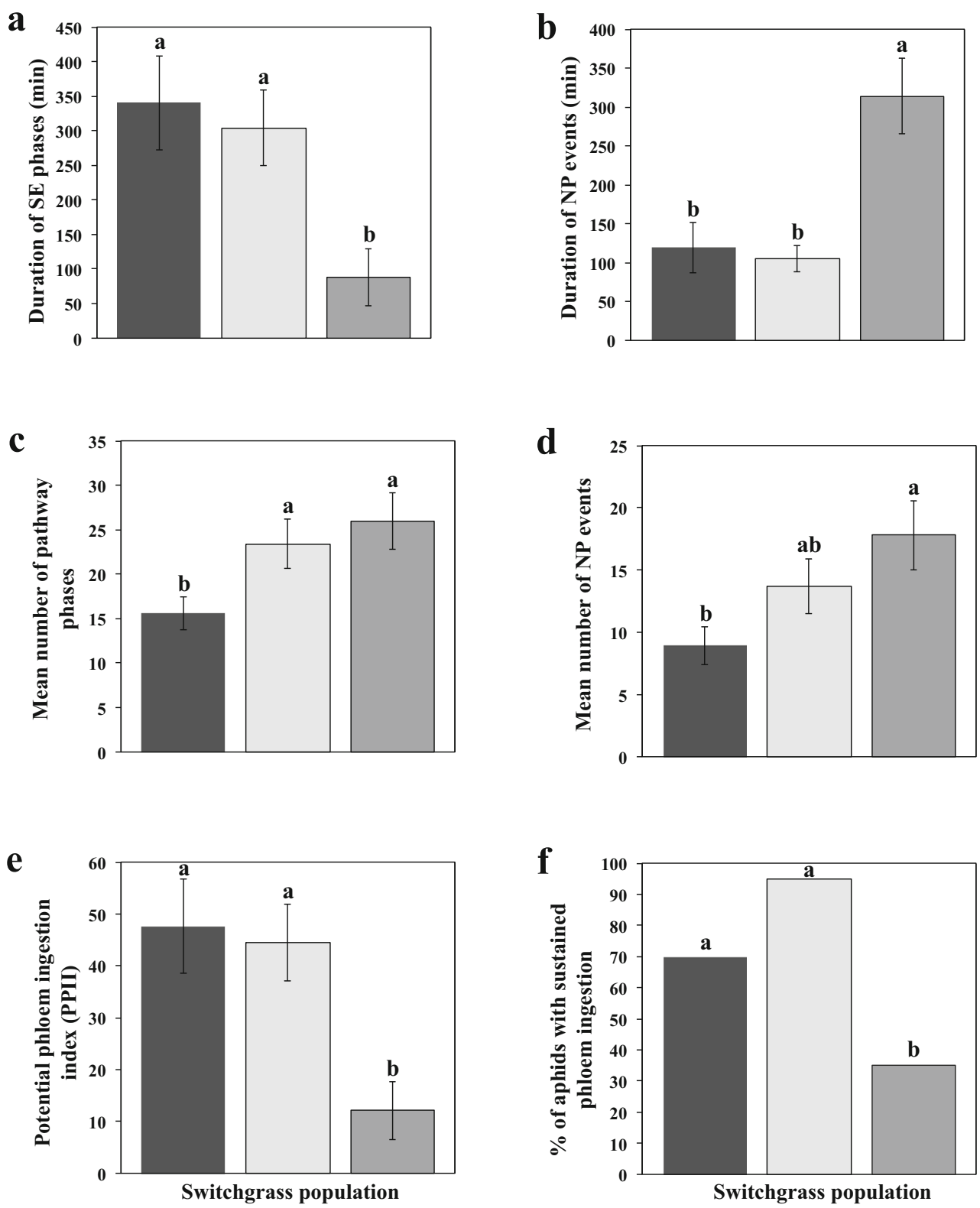

\section{Results}

Antixenosis Studies: Greenbugs (Schizaphis graminum)

Preferentially Choose $\mathrm{K} \times \mathrm{S}$ Plants as Hosts

There was a difference in the aphid preference for a host plant over time, leading to a significant interaction between switchgrass population and evaluation time (Fig. 1$)(F=1.87 ; \mathrm{df}=12$, $180 ; P=0.04)$. Due to the significant interaction between switchgrasses and evaluation time, simple effects were used to determine if differences existed among treatment means. At $24 \mathrm{~h}$ after introduction, $\mathrm{K} \times \mathrm{S}$ had significantly more aphids than Summer; however, Kanlow was not statistically different from either $\mathrm{K} \times \mathrm{S}$ or Summer. Likewise, at $48 \mathrm{~h}$ after aphid introduction, $\mathrm{K} \times \mathrm{S}$ had significantly more $S$. graminum than both Summer and Kanlow. The greatest difference in $S$. graminum preference was observed at $72 \mathrm{~h}$ after aphid introduction, where $\mathrm{K} \times \mathrm{S}$ again had a significant 3 -fold higher mean aphid number than Summer and over 4-fold higher mean aphid number than Kanlow. No significant differences in aphid numbers were detected between Summer and Kanlow plants at any time point.

Yellow Sugarcane Aphid (Sipha flava) Did Not Display Any Preferential Feeding Behavior

No significant differences were detected for overall $S$. flava preference between switchgrass populations and for $S$. flava preference within a given evaluation time (switchgrass population by evaluation time interaction). 


\section{Summer}
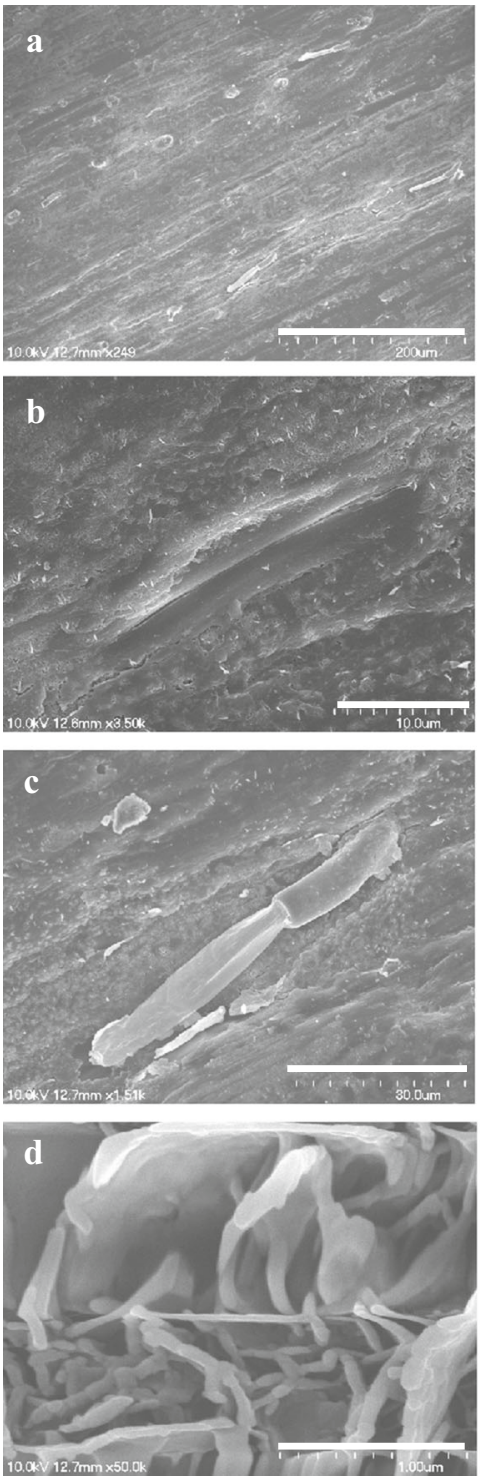

Fig. 3 Scanning electron micrographs of leaf surfaces among different switchgrass plants. a-d Summer, e-h Kanlow, and $\mathbf{i}-\mathbf{l} \mathrm{K} \times \mathrm{S}$. Regions around the stomata are shown $(\mathbf{b}, \mathbf{f}, \mathbf{j})$. Trichomes $(\mathbf{c}, \mathbf{k})$ and lack thereof (g). Higher magnification image of wax present on the leaves are shown
Kanlow
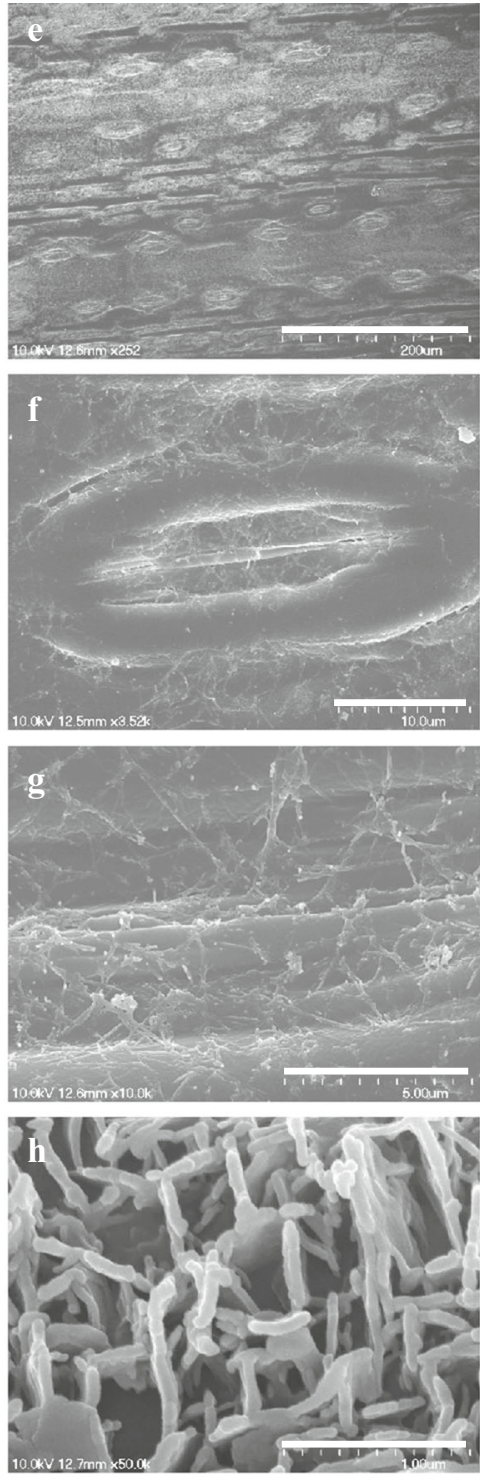

K x S
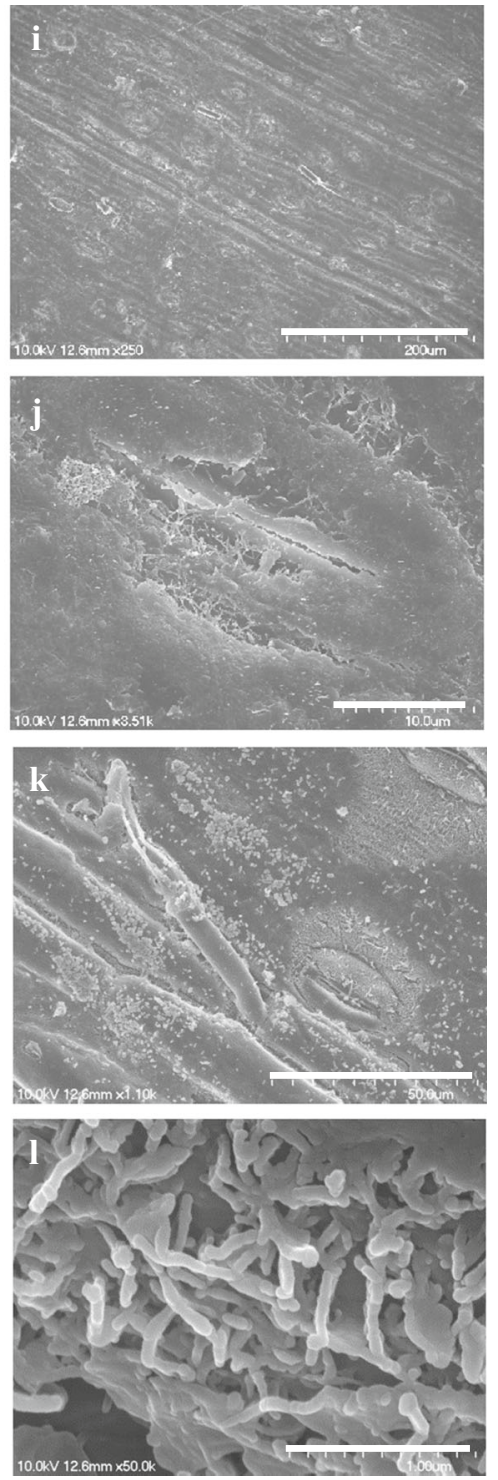

(d, h, l). White bars in $\mathbf{a}, \mathbf{e}, \mathbf{i}$ are $200 \mu \mathrm{m}$. White bars in $\mathbf{b}, \mathbf{f}, \mathbf{j}$ are $10 \mu \mathrm{m}$. White bars in $\mathbf{c}$ is $30 \mu \mathrm{m}$, in $\mathbf{g}$ is 5 , and $50 \mu \mathrm{m}$ in (k). White bars in $\mathbf{d}, \mathbf{h}, \mathbf{l}$ are $1 \mu \mathrm{m}$

EPG Studies: Greenbugs Fed More Effectively on Summer and $\mathrm{K} \times \mathrm{S}$ Plants

Analysis of variance determined that switchgrass effects were not significant for time to first probe or time to first sieve element phase from the start of the EPG recording (Online Resource 1). Further, after feeding was initiated, no significant differences were found between switchgrasses for time from the first probe to first sieve element phase, for parameters in the mean duration of pathway phases, xylem phases, first probe, and first sieve element phase (Online Resource 1). However, significant differences were detected for mean total duration of sieve element phases $(F=7.87 ; \mathrm{df}=2,54 ; P=$ $0.001)$ and non-probing events $(F=8.43 ; \mathrm{df}=2,57 ; P=$ 0.0006) (Fig. 2a, b, respectively). Specifically, aphids spent significantly less time overall in phloem sieve elements and significantly more time in non-probing on Kanlow, than when feeding on both $\mathrm{K} \times \mathrm{S}$ and Summer. Representative EPG data are shown in Online Resource 2.

No significant differences were observed for the number of potential drops, xylem phases, sieve element phases, and probes after the first sieve element phase (Online Resource 1). However, significant differences were recorded between switchgrasses in mean number of pathway phases $(F=4.10$; 
$\mathrm{df}=2,57 ; P=0.022)$ and non-probing events $(F=4.41 ; \mathrm{df}=2$, $57 ; P=0.017$ ) (Fig. 2c, d, respectively). In mean number of pathway phases, $\mathrm{K} \times \mathrm{S}$ had significantly fewer than both Summer and Kanlow. Again, $\mathrm{K} \times \mathrm{S}$ had significantly fewer nonprobing events than Kanlow; however, Summer was not significantly different from either group. Significant differences were also recorded between switchgrasses in the potential phloem ingestion index (PPII) $(F=9.40 ; \mathrm{df}=2,54 ; P=$ 0.0003 ) and percentage of $S$. graminum showing sustained phloem ingestion $(E>10 \mathrm{~min}$. $)(F=5.67 ; \mathrm{df}=2,57 ; P=$ 0.0057 ) (Fig. 2e, f). The potential phloem ingestion index (PPII) was significantly lower for Kanlow than all other switchgrasses. Similarly, Kanlow had significantly fewer aphids that demonstrated sustained phloem ingestion than both $\mathrm{K} \times \mathrm{S}$ and Summer, with only $35 \%$ of $S$. graminum able to sustain phloem ingestion for more than 10 min on Kanlow.

\section{Scanning Electron Microscopy: Leaf Surfaces Do Not} Indicate Differences Among These Populations

There were no obvious differences in overall leaf morphology, except for the presence of a few trichomes on the surfaces of Summer leaves (Fig. 3c), which appeared to be absent on leaves of Kanlow (Fig. $3 \mathrm{~g}$ ) and $\mathrm{K} \times \mathrm{S}$ (Fig. $3 \mathrm{k}$ ) plants. At higher magnifications, no apparent differences were observed in the type and amount of wax on the leaf surfaces (Fig. 3d, h, l).

\section{Metabolite Analysis: Kanlow Leaves Have Significantly Greater Levels of Oxalic Acid}

A preliminary screen of the polar metabolites present in leaf extracts from plants from the different populations was performed by GCMS (Fig. 4a; Table 1). Although some differences were seen in the relative levels of metabolite peaks and computed peak areas for individual metabolites (Table 1), the peak and peak area associated with oxalic acid (m/z 147) was minimal in the Summer and $\mathrm{K} \times \mathrm{S}$ plants, but was significantly elevated in Kanlow leaves $(F=13.61 ; \mathrm{df}=2,6 ; P=0.0059)$ (Fig. 4a, b).

\section{Discussion and Conclusions}

One of the most effective methods for controlling insect pests is plant resistance [43, 44]. Differential resistance to potential insect pests has been demonstrated in various switchgrass populations. Dowd and Johnson [12] found differential resistance among several octaploid switchgrass populations to Spodoptera frugiperda (J. E. Smith), with "Trailblazer" and "Blackwell" being the most resistant. Differential resistance was also demonstrated among four tetraploid switchgrass

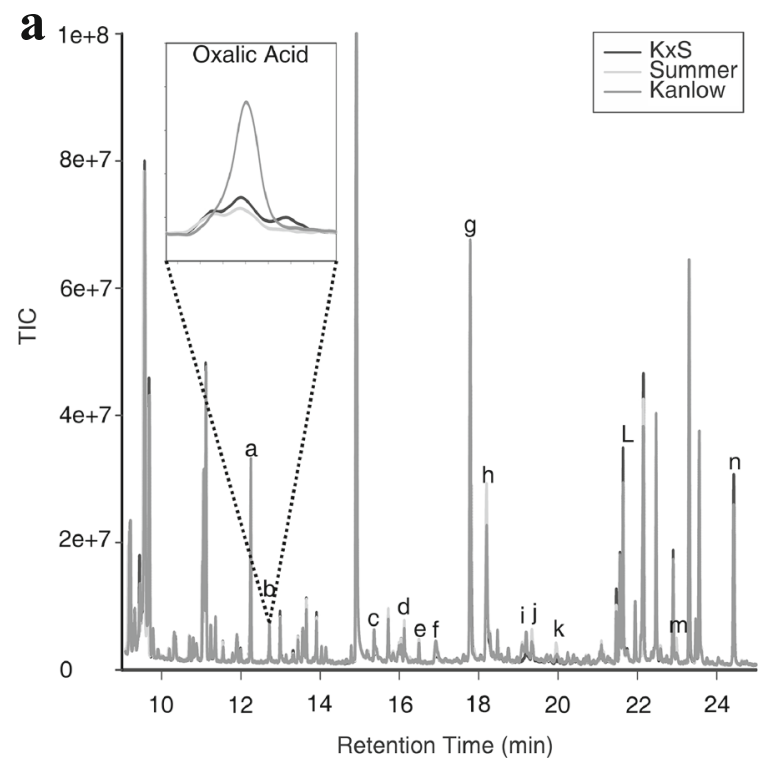

b

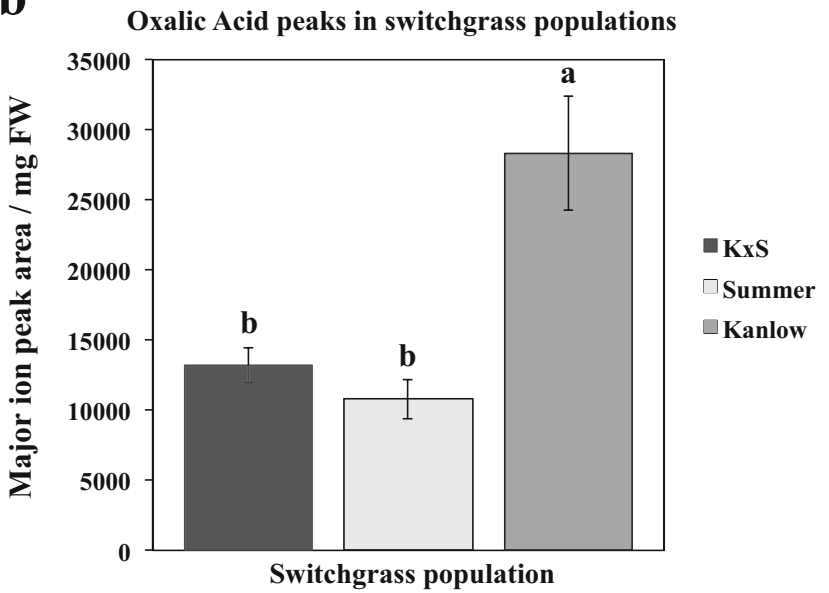

Fig. 4 Oxalic acid is significantly enriched in Kanlow leaf extracts. a Total ion chromatograms of leaf extracts from $\mathrm{K} \times \mathrm{S}$ (dark gray), Summer (light gray), and Kanlow (gray). Peaks labeled from $a$ to $n$ are metabolites identified with high confidence, and areas for these peaks are shown in Table 1. b Major ion peak area/mg FW in switchgrass populations for oxalic acid. Bars with the same letter are not significantly different $(P>0.05)$, LSD test

populations to two key aphid species, S. graminum and S. flava $[26,27]$. Multiple insect resistance mechanisms also appeared to be present in the full-sib progeny derived from a cross between an upland and a lowland tetraploid plant [13].

Choice studies for $S$. flava revealed no clear preference for the aphid among the three selected switchgrass populations. In contrast, choice studies for $S$. graminum revealed a clear preference for plants in the $\mathrm{K} \times \mathrm{S}$ population relative to all other switchgrasses. However, in both interactions, superficial plant characteristics [29, 35] (see Fig. 3) do not appear to play an important role in influencing the settling and feeding behavior of the aphids on these switchgrasses. The lack of an effect of superficial 
Table 1 Metabolite concentrations (area under major ion) in extracts from different switchgrasses

\begin{tabular}{lllll}
\hline ID & Compound & Area under peaks \pm SEM $^{\mathrm{a}}$ & & \\
\cline { 3 - 5 } & & $\mathrm{K} \times \mathrm{S}$ & Summer & Kanlow \\
\hline $\mathrm{a}$ & Alanine & $13,938 \pm 923 \mathrm{~b}$ & $20,822 \pm 2,103 \mathrm{a}$ & $16,916 \pm 615 \mathrm{ab}$ \\
$\mathrm{c}$ & Glycine & $13,172 \pm 242 \mathrm{~b}$ & $24,452 \pm 3,352 \mathrm{a}$ & $25,508 \pm 1,686 \mathrm{a}$ \\
$\mathrm{d}$ & Serine & $11,169 \pm 1,622 \mathrm{~b}$ & $27,848 \pm 2,690 \mathrm{a}$ & $14,126 \pm 1,101 \mathrm{~b}$ \\
$\mathrm{e}$ & Threonine & $6,046 \pm 441 \mathrm{~b}$ & $13,108 \pm 1,852 \mathrm{a}$ & $6,717 \pm 327 \mathrm{~b}$ \\
$\mathrm{f}$ & Aspartate & $14,288 \pm 1,240 \mathrm{~b}$ & $28,715 \pm 4,369 \mathrm{a}$ & $25,476 \pm 1,137 \mathrm{a}$ \\
$\mathrm{g}$ & Malate & $131,724 \pm 7,654 \mathrm{a}$ & $124,767 \pm 7,181 \mathrm{a}$ & $126,686 \pm 2,855 \mathrm{a}$ \\
$\mathrm{h}$ & Proline & $29,005 \pm 323 \mathrm{~b}$ & $52,042 \pm 4,967 \mathrm{a}$ & $31,280 \pm 437 \mathrm{~b}$ \\
$\mathrm{i}$ & 2-Ketoglutarate & $9,897 \pm 536 \mathrm{ab}$ & $11,122 \pm 711 \mathrm{a}$ & $9,221 \pm 135 \mathrm{~b}$ \\
$\mathrm{j}$ & Glutamine & $15,733 \pm 1,977 \mathrm{~b}$ & $32,725 \pm 3,763 \mathrm{a}$ & $13,269 \pm 1,187 \mathrm{~b}$ \\
$\mathrm{k}$ & Asparagine & $1,591 \pm 692 \mathrm{~b}$ & $17,089 \pm 5,863 \mathrm{a}$ & $4,095 \pm 554 \mathrm{~b}$ \\
1 & Isocitrate & $96,940 \pm 7,914 \mathrm{a}$ & $76,503 \pm 3,923 \mathrm{~b}$ & $70,572 \pm 3,676 \mathrm{~b}$ \\
$\mathrm{~m}$ & Ascorbate & $1,966 \pm 62 \mathrm{a}$ & $2,314 \pm 289 \mathrm{a}$ & $1,788 \pm 201 \mathrm{a}$ \\
$\mathrm{n}$ & Myoinositol & $84,894 \pm 5,901 \mathrm{a}$ & $66,895 \pm 4,625 \mathrm{~b}$ & $64,562 \pm 1,244 \mathrm{~b}$ \\
\hline
\end{tabular}

The peaks for each compound are shown in Fig. 4a

${ }^{a}$ Compound means within the same row followed by the same letter indicate no significant differences $(P \leq 0.05)$, LSD test

plant characteristics was also corroborated by the EPG studies, which revealed no significant differences in the time to first probe in any of the switchgrasses.

EPG parameters indicated that the resistance factors in the selected switchgrasses were not located in the peripheral layers of the plant tissue. Resistance factors in the epidermis and mesophyll may be indicated by a large number of test probes and an increased time to reach the first phloem sieve element phase [1]; however, no differences were recorded among any of the switchgrasses for time to reach the first sieve element phase. This indicates that aphids did not encounter physical barriers along the peripheral tissues. Similarly, aphids had a statistically similar time to first sieve element phase from first probe for all switchgrass populations. Time to first sieve element phase from first probe has been considered to be a more meaningful parameter in localizing plant resistance since it corrects for potential differences in time to reach the first sieve element phase due to delayed probing as the result of epidermal factors [53]. Accordingly, a lack of differences for this parameter demonstrated that phloem was not harder to reach in any of the switchgrasses tested.

Conversely, several of the parameters tested indicate that resistance factors may be associated with phloem sieve elements. Although no differences were recorded in aphid access to phloem sieve elements, S. graminum were unable to spend as much time feeding in the sieve elements on Kanlow, spending over 3-fold more time in the sieve elements on $\mathrm{K} \times$ $\mathrm{S}$ and Summer, relative to Kanlow. In addition, Kanlow had a PPII value that was significantly lower than both $\mathrm{K} \times \mathrm{S}$ and Summer. The PPII parameter is a corrected index used to determine the acceptability of phloem, measuring the percentage of time the insect spends in sieve elements, with the registration time to the first sieve element subtracted [17, 53]. Correspondingly, 70 and $95 \%$ of aphids were able to feed in phloem sieve elements for sustained periods (i.e., longer than $10 \mathrm{~min}$ ) on $\mathrm{K} \times \mathrm{S}$ and Summer, respectively, while only $35 \%$ of aphids tested on Kanlow were able to achieve sustained phloem feeding. Collectively, these data demonstrate that Kanlow does have a significant impact on $S$. graminum feeding behavior and indicate that resistant factors are likely located in the phloem sieve elements. Differences in phloem acceptability likely explain the significant increase in duration and number of non-probing events as well as the number of pathway phases in Kanlow relative to $\mathrm{K} \times \mathrm{S}$. Because each phase is mutually exclusive, $S$. graminum feeding on the susceptible $\mathrm{K} \times \mathrm{S}$ would have less time available for other phases, such as pathway and non-probing, since more time was spent in the sieve element phase [53]. However, aphids feeding on resistant plants may continue probing, searching for a suitable feeding site and leading to a greater number of probes and pathway phases.

Phloem-based mechanisms of resistance to aphids have previously been reported, including resistance in melon genotypes (Cucumis melo L.) to the cotton melon aphid, Aphis gossypii [16]. Recently, Myzus persicae (Sulzer) was shown to have higher mortality on tobacco plants with atypical phloem sterol content, suggesting the possibility that some sterols (or sterol derivatives) may be deleterious to aphids [4, 5]. Still, the underlying mechanisms for resistance located in phloem tissue may be physical (i.e., difficulty overcoming phloem wound response), in addition to chemical mechanisms (i.e., deterrent compounds in sieve tubes) $[29,52]$. 
Phloem feeding is particularly important for aphids, providing them with the necessary nutrients not available in xylem sap [34]; limiting the nutrient uptake by the aphids may also negatively affect aphid demographics. Indeed, the antibiosis and antixenosis categories of resistance often overlap and may be difficult to distinguish, since a strong deterrent effect may initiate aberrant behavior in an insect, resulting in a weakened physiological condition which could produce an antibiotic effect [43]. Previous work on the categories of resistance in no-choice studies with the same selected switchgrass populations suggested that Kanlow possesses high levels of antibiosis to both $S$. graminum and S. flava $[26,27]$ and antixenosis to $S$. graminum (this study). A preliminary metabolite screen demonstrated that oxalic acid levels were elevated in Kanlow. Oxalic acid is a prevalent compound in plants and has been implicated in plant defense [14], including as a feeding inhibitor/toxin to aphids [20, 23, 28]. Whether higher oxalate levels contribute to the overall resistance of Kanlow plants to the S. flava and S. graminum is not known, but could be investigated in future studies.

This research provides the first detailed documentation of the feeding behavior of aphids on switchgrass. The results indicate that Kanlow markedly altered the probing behavior and sieve element acceptance of $S$. graminum, relative to the other switchgrasses tested. In combination with earlier results $[25,27]$ and data presented here indicate that Kanlow may possess both antibiosis and antixenosis categories of resistance to $S$. graminum. Combinations of resistance categories are often reported, including many examples of antibiosis and antixenosis together $[9,11,15,16,18,19,29]$. The combination of multiple categories and mechanisms of resistance may lower the probability or at least delay aphid populations from overcoming resistant switchgrasses; therefore, Kanlow should be of considerable interest for any switchgrass breeding program for improved biomass feedstocks. Moreover, prior work has shown Kanlow possesses antibiosis to $S$. flava, in addition to $S$. graminum. Multispecies resistance in combination with the potential of multiple resistance categories is a very important finding and should not be understated. However, while Kanlow possesses high levels of resistance to $S$. flava and $S$. graminum, it does not imply that the resistance mechanisms are the same for both aphid species. Resistance to aphids is generally very species specific [52]; thus, future work should focus on detailing $S$. flava feeding behavior on switchgrasses to determine the possible mechanisms and location of resistance to S. flava. Identification of resistance mechanisms is of great importance, in order to provide effective integrated pest management strategies and possibly informing foresight for resistance management (i.e., managing insect countermeasures to host resistance). Therefore, future research should also concentrate on improving our understanding of specific mechanisms that contribute to plant resistance to aphids.

Acknowledgments We gratefully acknowledge Z. B. Mayo for reviewing the manuscript and $\mathrm{K}$. P. Vogel for providing the switchgrass germ plasm for these studies. We thank Dr. Han Chen, Microscopy Core Facility, University of Nebraska at Lincoln, for the help with the SEM. This research was supported in part by the USDA-National Institute of Food and Agriculture grant number 2011-67009-30096 and by the USDA-ARS CRIS project 5440-21000-030-00D. The US Department of Agriculture, Agricultural Research Service, is an equal opportunity/ affirmative action employer and all agency services are available without discrimination. Mention of commercial products and organizations in this manuscript is solely to provide specific information. It does not constitute endorsement by USDA-ARS over other products and organizations not mentioned.

\section{References}

1. Alvarez AE, Tjallingii WF, Garzo E, Vleeshouwers V, Dicke M, Vosman B (2006) Location of resistance factors in the leaves of potato and wild tuber-bearing Solanum species to the aphid Myzus persicae. Entomol Exp Appl 121:145-157

2. Annan IB, Schaefers GA, Tingey WM, Tjallingii WF (1997) Stylet activity of cowpea aphid (Homoptera: Aphididae) on leaf extracts of resistant and susceptible cowpea cultivars. J Insect Behav 10(5):603-618

3. Annan IB, Tingey WM, Schaefers GA, Tjallingii WF, Backus EA, Saxena KN (2000) Stylet penetration activities by Aphis craccivora (Homoptera: Aphididae) on plants and excised plant parts of resistant and susceptible cultivars of cowpea (Leguminosae). Ann Entomol Soc Am 93(1):133-140

4. Behmer ST, Grebenok RJ, Douglas AE (2011) Plant sterols and host plant suitability for a phloem-feeding insect. Funct Ecol 25(3):484 491. doi:10.1111/j.1365-2435.2010.01810.x

5. Behmer ST, Olszewski N, Sebastiani J, Palka S, Sparacino G, Sciarno E, Grebenok RJ (2013) Plant phloem sterol content: forms, putative functions, and implications for phloem-feeding insects. Front Plant Sci 4:370. doi:10.3389/fpls.2013.00370

6. Blackman RL, Eastop VF (2000) Aphids on the world's crops, an identification and information guide, 2nd edn. Wiley, West Sussex

7. Burd JD, Prasifka JR, Bradshaw JD (2012) Establishment and host effects of cereal aphids on switchgrass (Panicum virgatum L.) cultivars. Southwest Entomol 37(2):115-122

8. Casler MD (2012) Switchgrass breeding, genetics, and genomics. In: Monti A (ed) Switchgrass. Springer, London, pp $29-53$

9. Castro AM, Martin A, Martin LM (1996) Location of genes controlling resistance to greenbug (Schizaphis graminum Rond.) in Hordeum chilense. Plant Breed 115:335-338

10. Crompton DS, Ode PJ (2010) Feeding behavior analysis of the soybean aphid (Hemiptera: Aphididae) on resistant soybean 'Dowling'. J Econ Entomol 103(3):648-653

11. Diaz-Montano J, Reese JC, Louis J, Campbell LR, Schapaugh WT (2007) Feeding behavior by the soybean aphid (Hemiptera: Aphididae) on resistant and susceptible soybean genotypes. J Econ Entomol 100(3):984-989

12. Dowd PF, Johnson ET (2009) Differential resistance of switchgrass Panicum virgatum $\mathrm{L}$. lines to fall armyworms Spodoptera frugiperda (J. E. Smith). Genet Resour Crop Evol 56(8):1077-1089. doi:10. 1007/s10722-009-9430-6

13. Dowd PF, Sarath G, Mitchell RB, Saathoff AJ, Vogel KP (2012) Insect resistance of a full sib family of tetraploid switchgrass 
Panicum virgatum L. with varying lignin levels. Genet Resour Crop Evol 60(3):975-984. doi:10.1007/s10722-012-9893-8

14. Dunwell JM, Gibbings JG, Mahmood T, Saqlan Naqvi SM (2008) Germin and Germin-like proteins: evolution, structure, and function. Crit Rev Plant Sci 27(5):342-375. doi:10.1080/07352680802333938

15. Eickhoff TE, Heng-Moss TM, Baxendale FP, Foster JE (2008) Levels of tolerance, antibiosis, and antixenosis among resistant buffalograsses and zoysiagrasses. J Econ Entomol 101(2):533-540

16. Garzo E, Soria C, Gomez-Guillamon ML, Fereres A (2002) Feeding behavior of Aphis gossypii on resistant accessions of different melon genotypes (Cucumis melo). Phytoparasitica 30(2):129-140

17. Girma M, Wilde GE, Reese JC (1992) Russian wheat aphid (Homoptera: Aphididae) feeding behavior on host and nonhost plants. J Econ Entomol 85(2):395-401

18. Hawley CJ, Paeirs FB, Randolph TL (2003) Categories of resistance at different growth stages in halt, a winter wheat resistant to the Russian wheat aphid (Homoptera: Aphididae). J Econ Entomol 96(1):214-219

19. Heng-Moss TM, Baxendale FP, Riordan TP, Lee K (2003) Chinch bug-resistant buffalograss: an investigation of tolerance, antixenosis, and antibiosis. J Econ Entomol 96(6):1942-1951

20. Hudgins JW, Krekling T, Franceschi VR (2003) Distribution of calcium oxalate crystals in the secondary phloem of conifers: a constitutive defense mechanism? New Phytol 159(3):677-690. doi: 10.1046/j.1469-8137.2003.00839.x

21. Jiang YX, Nombela G, Muniz M (2001) Analysis by DC-EPG of the resistance to Bemisia tabaci on an Mi-tomato line. Entomol Exp Appl 99:295-302

22. Jiang YX, Walker GP (2001) Pathway phase waveform characteristics correlated with length and rate of stylet advancement and partial stylet withdrawal in AC electrical penetration graphs of adult whiteflies. Entomol Exp Appl 101:233-246

23. Karatolos N, Hatcher PE (2009) The effect of acetylsalicylic acid and oxalic acid on Myzus persicae and Aphidius colemani. Entomol Exp Appl 130(1):98-105. doi:10.1111/j.1570-7458.2008.00797.x

24. Kindler SD, Dalrymple RL (1999) Relative susceptibility of cereals and pasture grasses to the yellow sugarcane aphid (Homoptera: Aphididae). J Agric Urban Entomol 16(2):113-122

25. Koch K, Bradshaw J, Heng-Moss T, Sarath G (2014) Categories of resistance to greenbug and yellow sugarcane aphid (Hemiptera: Aphididae) in three tetraploid switchgrass populations. Bioenergy Res:1-10. doi:10.1007/s12155-014-9420-1

26. Koch KG, Bradshaw JD, Heng-Moss TM, Sarath G (2014) Categories of resistance to greenbug and yellow sugarcane aphid (Hemiptera: Aphididae) in three tetraploid switchgrass populations. Bioenergy Res. doi:10.1007/s12155-014-9420-1

27. Koch KG, Fithian R, Heng-Moss TM, Bradshaw JD, Sarath G, Spilker C (2014) Evaluation of tetraploid switchgrass (Poales: Poaceae) populations for host suitability and differential resistance to four cereal aphids. J Econ Entomol 107(1):424-431

28. Korth KL, Doege SJ, Park SH, Goggin FL, Wang Q, Gomez SK, Liu G, Jia L, Nakata PA (2006) Medicago truncatula mutants demonstrate the role of plant calcium oxalate crystals as an effective defense against chewing insects. Plant Physiol 141(1):188-195. doi:10.1104/ pp. 106.076737

29. Le Roux V, Dugravot S, Campan E, Dubois F, Vincent C, Giordanengo P (2008) Wild Solanum resistance to aphids: antixenosis or antibiosis? J Econ Entomol 101(2):584-591

30. McLean DL, Kinsey MG (1964) A technique for electronically recording aphid feeding and salivation. Nature 202:1358-1359

31. Michels GJ Jr (1986) Graminaceous North American host plants of the greenbug with notes on biotypes. Southwest Entomol 11(2):55-66

32. Moore KJ, Moser LE, Vogel KP, Waller SS, Johnson BE, Pedersen JF (1991) Describing and quantifying growth stages of perennial forage grasses. Agron J 83(6):1073-1077
33. Palmer NA, Saathoff AJ, Kim J, Benson A, Tobias CM, Twigg P, Vogel KP, Madhavan S, Sarath G (2011) Next-generation sequencing of crown and rhizome transcriptome from an upland, tetraploid switchgrass. Bioenergy Res 5(3):649-661. doi:10.1007/s12155011-9171-1

34. Powell G, Hardie J (2002) Xylem ingestion by winged aphids. Entomol Exp Appl 104(1):103-108

35. Powell G, Tosh CR, Hardie J (2006) Host plant selection by aphids: behavioral, evolutionary, and applied perspectives. Annu Rev Entomol 51:309-330

36. Prado E, Tjallingii WF (1994) Aphid activities during sieve element punctures. Entomol Exp Appl 72:157-165

37. Prado E, Tjallingii WF (1997) Effects of previous plant infestation on sieve element acceptance by two aphids. Entomol Exp Appl 82:189 200

38. Reese JC, Tjallingii WF, van Helden M, Prado E (2000) Waveform comparisons among $\mathrm{AC}$ and $\mathrm{DC}$ systems for electronic monitoring of aphid feeding behavior. In: Walker GP, Backus EA (eds) Principles and applications of electronic monitoring and other techniques in the study of homopteran feeding behavior. Thomas Say Publications in Entomology, Entomological Society of America, Lanham

39. Roessner U, Patterson JH, Forbes MG, Fincher GB, Langridge P, Bacic A (2006) An investigation of boron toxicity in barley using metabolomics. Plant Physiol 142(3):1087-1101. doi:10.1104/pp. 106.084053

40. Sarria E, Cid M, Garzo E, Fereres A (2009) Excel workbook for automatic parameter calculation of EPG data. Comput Electron Agric 67:35-42

41. SAS Institute (2008) PROC user's manual, 92nd edn. SAS Institute, Cary

42. Shapiro SS, Francia RS (1972) An approximate analysis of variance test for normality. J Am Stat Assoc 67:215-216

43. Smith CM (2005) Plant resistance to arthropods. Springer, Dordrecht

44. Smith CM, Boyko EV (2007) The molecular bases of plant resistance and defense responses to aphid feeding: current status. Entomol Exp Appl 122(1):1-16

45. Spiller NJ, Koenders L, Tjallingii WF (1990) Xylem ingestion by aphids - a strategy for maintaining water balance. Entomol Exp Appl 55:101-104

46. Stamm MD, Heng-Moss TM, Baxendale FP, Reese JC, Siegfried BD, Hunt TE, Gaussoin RE, Blankenship EE (2013) Effects of thiamethoxam seed treatments on soybean aphid (Hemiptera: Aphididae) feeding behavior. J Econ Entomol 106(6):2384-2390

47. Tjallingii WF (1978) Electronic recording of penetration behaviour by aphids. Entomol Exp Appl 24:721-730

48. Tjallingii WF (1985) Membrane potentials as an indication for plant cell penetration by aphid stylets. Entomol Exp Appl 38:187-193

49. Tjallingii WF (1988) Electrical recording of stylet penetration activities. In: Minks AK, Harrewijn P (eds) Aphids, their biology, natural enemies and control, vol 2B. Elsevier, Amsterdam, pp 95-108

50. Tjallingii WF (1990) Continuous recording of stylet penetration activities by aphids. In: Campbell RK, Eikenbary RD (eds) Aphidplant genotype interactions. Elsevier, Amsterdam, pp 89-99

51. Tjallingii WF (1994) Sieve element acceptance by aphids. Eur J Entomol 91:47-52

52. Tjallingii WF (2006) Salivary secretions by aphids interacting with proteins of phloem wound responses. J Exp Bot 57(4):739-745

53. van Helden M, Tjallingii WF (2000) Experimental design and analysis in EPG experiments with emphasis on plant resistance research. In: Walker GP, Backus EA (eds) Principles and applications of electronic monitoring and other techniques in the study of homopteran feeding behavior. Thomas Say Publications in Entomology, Entomological Society of America, Lanham 
Online Resource 1 Comparison of EPG parameters (mean \pm SEM) for Schizaphis graminum feeding on switchgrass populations.

$\operatorname{Mean} \pm \operatorname{SEM}^{\mathrm{a}}$

\begin{tabular}{|c|c|c|c|}
\hline Feeding Variable & $\mathbf{K x S}$ & Summer & Kanlow \\
\hline Time to $1^{\text {st }}$ probe ${ }^{b}$ & $21.4 \pm 7.6 \mathrm{a}$ & $11.1 \pm 3.9 \mathrm{a}$ & $26.5 \pm 14.9 \mathrm{a}$ \\
\hline Time to $1^{\text {st }} \mathrm{SE}^{1}$ phase & $181.9 \pm 30.6 \mathrm{a}$ & $238.7 \pm 37.9 \mathrm{a}$ & $162.2 \pm 24.3 \mathrm{a}$ \\
\hline $\begin{array}{l}\text { Time from } 1^{\text {st }} \text { probe } \\
\text { to } 1^{\text {st }} \mathrm{SE} \text { phase }\end{array}$ & $159.5 \pm 30.6 \mathrm{a}$ & $227.6 \pm 38.6 \mathrm{a}$ & $147.6 \pm 22.8 \mathrm{a}$ \\
\hline Duration of pathway phases ${ }^{b}$ & $401.5 \pm 51.4 \mathrm{a}$ & $434.0 \pm 41.4 \mathrm{a}$ & $437.4 \pm 45.6 \mathrm{a}$ \\
\hline Duration of xylem phases & $56.9 \pm 11.9 \mathrm{a}$ & $60.2 \pm 9.3 \mathrm{a}$ & $71.1 \pm 12.9 \mathrm{a}$ \\
\hline Duration of $1^{\text {st }}$ probe & $85.0 \pm 45.2 \mathrm{a}$ & $69.7 \pm 45.3 \mathrm{a}$ & $52.9 \pm 21.9 a$ \\
\hline Duration of $1^{\text {st }} \mathrm{SE}$ phase & $81.8 \pm 50.3 \mathrm{a}$ & $53.8 \pm 39.2 \mathrm{a}$ & $30.7 \pm 27.1 \mathrm{a}$ \\
\hline Potential drops & $152.1 \pm 21.1 \mathrm{a}$ & $154.7 \pm 21.8 \mathrm{a}$ & $183.9 \pm 21.4 \mathrm{a}$ \\
\hline Xylem phases & $2.4 \pm 0.4 \mathrm{a}$ & $2.7 \pm 0.4 \mathrm{a}$ & $2.9 \pm 0.4 \mathrm{a}$ \\
\hline SE phases & $4.8 \pm 0.9 \mathrm{a}$ & $7.2 \pm 1.1 \mathrm{a}$ & $5.7 \pm 0.9 \mathrm{a}$ \\
\hline Probes after $1^{\text {st }}$ SE phase & $6.9 \pm 1.6 \mathrm{a}$ & $9.7 \pm 2.4 \mathrm{a}$ & $11.3 \pm 2.3 \mathrm{a}$ \\
\hline
\end{tabular}


A

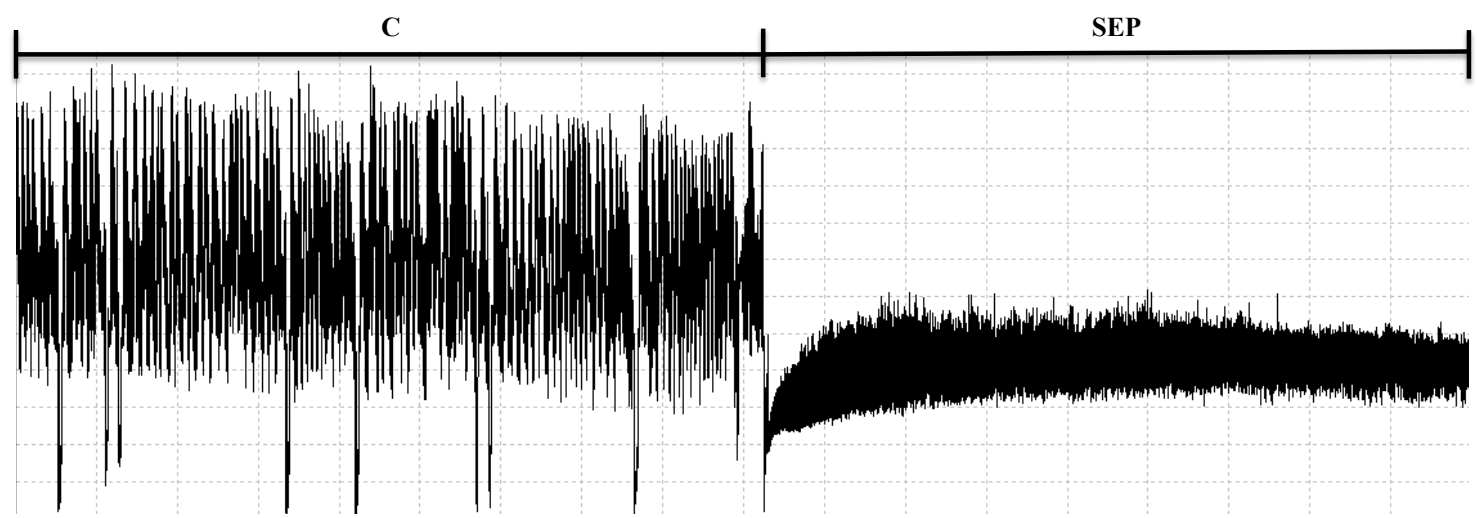

B
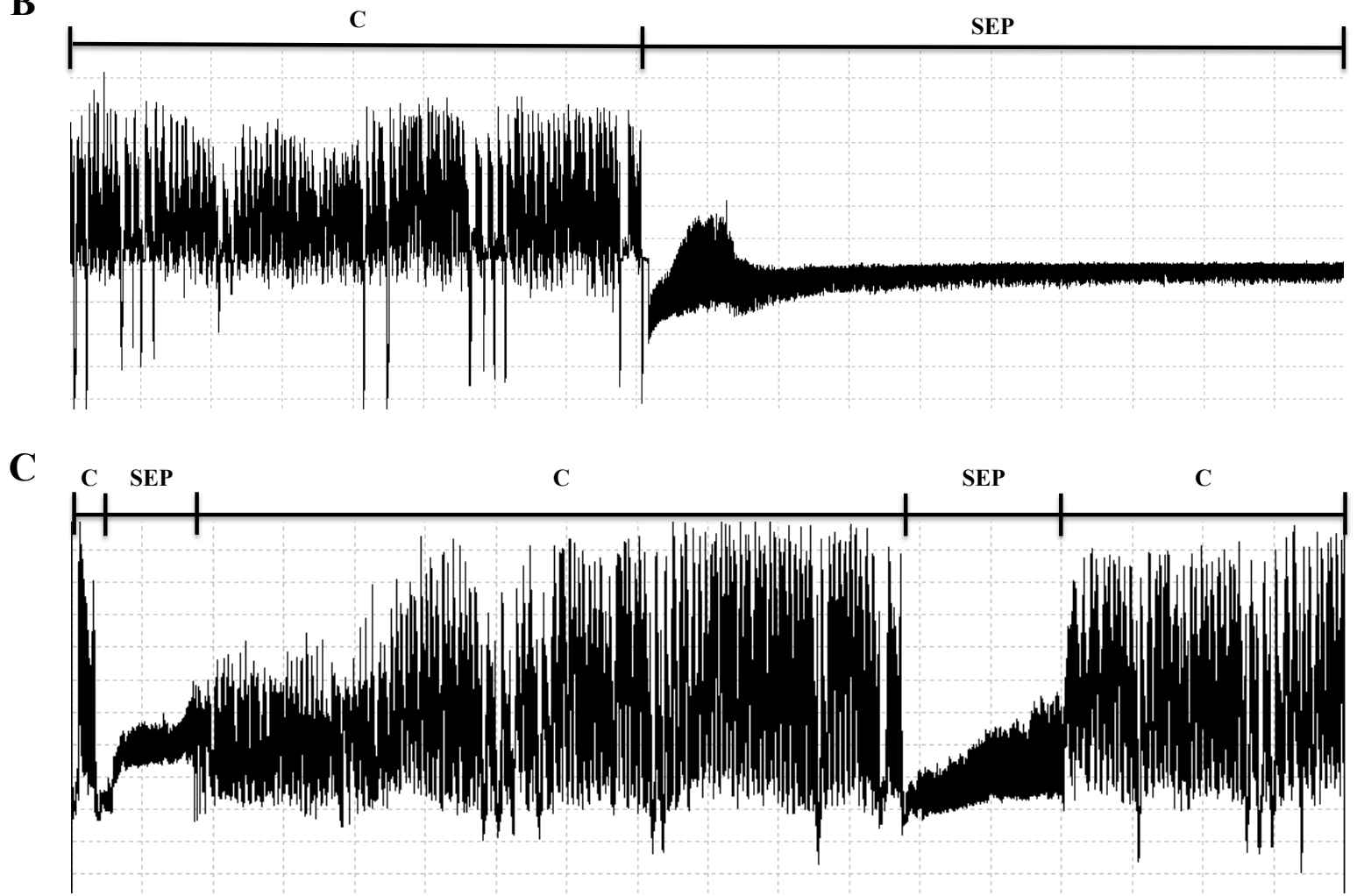

Online Resource 2 Representative $1 \mathrm{~h}$ EPG recordings for Summer (panel A), KxS (panel B) and Kanlow (panel C). Recordings demonstrate pathway (waveform C) into phloem sieve element phase (SEP). Representative data for Summer and KxS exhibit sustained phloem ingestion (SEP > 10 min); aphids reach SEP in hour 6 and 4, respectively, sustaining phloem ingestion for the remainder of the recording. Representative recording for Kanlow (hour 2) displays short phloem ingestion (SEP $<10$ $\mathrm{min}$ ), followed again by pathway events (waveform C). 